\title{
Successful management of refractory respiratory failure caused by avian influenza H7N9 and secondary organizing pneumonia: a case report and literature review
}

\author{
Hangyong He* (iD, Hao Wang, Xuyan Li, Xiao Tang, Bing Sun and Zhaohui Tong
}

\begin{abstract}
Backgroud: Organizing pneumonia (OP) is a rare complication of influenza infection that has substantial morbidity. We report the first case of OP associated with avian influenza H7N9 infection that had significant improvement with corticosteroid treatment.

Case presentation: A 35-year-old male admitted to intensive care unit because of respiratory failure. He was diagnosed as severe pneumonia caused by avian influenza H7N9 viral infection. After initial clinical improvement supported by extracorporeal membrane oxygenation (ECMO), the patient's condition worsened with persistent fever, refractory hypoxemia. Chest x-rays and computed tomographies showed areas of consolidation and ground glass opacification. Although OP was suspected and $1 \mathrm{mg} / \mathrm{kg}$ methylprednisolone was used, the patient's condition didn't improved considerably. An open lung biopsy was performed, and histopathological examination of the specimen was compatible with OP. The patient was treated with methylprednisolone $1.5 \mathrm{mg} / \mathrm{kg}$ for 5 days. ECMO was weaned on day 15, and he was discharged on day 71 with good lung recovery.

Conclusions: To the best of our knowledge, this was the first case of successful management of refractory severe respiratory failure caused by avian influenza H7N9 infection complicated with OP. Refractory hypoxia with clinical manifestation and radiological findings compatible with OP, a differential diagnosis should be considered among patients at the second or third week of influenza H7N9 infection, especially in patients with clinical condition deteriorated after the primary influenza pneumonia was controlled. And a steroid dose of methylprednisolone 1.5 $\mathrm{mg} / \mathrm{kg}$ may be suggested for treatment of OP associated with avian influenza H7N9 infection.
\end{abstract}

Keywords: Organizing pneumonia, Avian influenza H7N9, Respiratory failure

\section{Background}

Human infected with avian influenza A H7N9 virus were first confirmed on March 30th, 2013 in China [1, 2], with high incidence of severe respiratory failure, high intensive care unit (ICU) admission and mortality. The development of organizing pneumonia (OP) has been reported in patients with influenza A, H1N1 and

\footnotetext{
* Correspondence: yonghang2004@sina.com

Department of Respiratory and Critical Care Medicine, Beijing Institute of Respiratory Medicine, Beijing Key Laboratory of Respiratory and Pulmonary Circulation, Beijing Chao-Yang Hospital, Capital Medical University, Beijing, No. 8 Gongren Tiyuchang Nanlu, Chaoyang District, Beijing (100020), China
}

influenza $\mathrm{B}$, and a high incidence of more than $10 \%$ of $\mathrm{OP}$ in influenza A H1N1 was reported in one case series [3-5]. In this report, we describe the first case of OP associated with avian influenza H7N9 infection.

\section{Case presentation}

A 35 year-old male, non-smoker, with a history of poultry contact 10 days before, was admitted to emergency room with fever and cough for 4 days (considered as day 1 for the case timeline). Physical examination showed bilateral moist crackles. Laboratory tests showed

(c) The Author(s). 2019 Open Access This article is distributed under the terms of the Creative Commons Attribution 4.0 International License (http://creativecommons.org/licenses/by/4.0/), which permits unrestricted use, distribution, and reproduction in any medium, provided you give appropriate credit to the original author(s) and the source, provide a link to the Creative Commons license, and indicate if changes were made. The Creative Commons Public Domain Dedication waiver (http://creativecommons.org/publicdomain/zero/1.0/) applies to the data made available in this article, unless otherwise stated. 
white blood cell count (WBC) was $5.75 \times 10^{9} / \mathrm{L}$ (and it became to $1.35 \times 10^{9} / \mathrm{L}$ two days later), $\mathrm{C}$ reactive protein (CRP) was $13.3 \mathrm{mg} / \mathrm{L}$, and procalcitonin (PCT) was $<0.1 \mathrm{ng} / \mathrm{ml}$. Chest $\mathrm{x}$-ray and chest computed tomography (CT) showed bilateral ground-glass opacities (GGO) and consolidation (Fig. 1). Moxifloxacin $400 \mathrm{mg}$ daily was administered for two days. And his condition deteriorated with dyspnea and severe respiratory failure, and the blood gas analysis showed $\mathrm{PaO}_{2}$ was $58 \mathrm{mmHg}$ under oxygen mask with a $\mathrm{FiO} 2$ of 0.8 . He was transferred to our intensive care unit (ICU) supported with noninvasive ventilation (NIV) and intubated $3 \mathrm{~h}$ later. Mechanical ventilation with peak inspiratory pressure (PIP) of $32 \mathrm{~cm} \mathrm{H}_{2} \mathrm{O}$, positive end expiratory pressure (PEEP) of $20 \mathrm{~cm} \mathrm{H} \mathrm{H}_{2} \mathrm{O}$ and $\mathrm{FiO}_{2}$ of 1.0 could not maintain the oxygenation. As his $\mathrm{PaO}_{2} / \mathrm{FiO}_{2}$ ratio less than $50 \mathrm{mmHg}$ lasted for $3 \mathrm{~h}$, the venovenous-extracorporeal membrane oxygenation (VV-ECMO) was established. The microscopic examination, culture and galactomannan detection from serum and bronchial-alveolar lavage fluid (BALF) for virus PCR, fungal, and the culture for bacteria and the microscopic examination for bacteria and tuberculosis were done at ICU admission. The nucleic acid polymerase chain reaction (PCR) for influenza H7N9 virus of sputum specimen turned out to be positive and oseltamivir phosphate was initiated $(150 \mathrm{mg}$ twice daily for 2 weeks after the PCR of the virus were negative for two consecutive tests.). As the PCT rose to $4.84 \mathrm{ng} / \mathrm{ml}$, and the galactomannan detection was positive (2.52 from serum sample and 1.21 from BALF sample), vancomycin, imipenem cilastatin and caspofungin were applied. Hydrocortisone $300 \mathrm{mg}$ daily for 3 days was also used for septic shock.

ECMO was weaning off on day 15 (the time of ECMO supporting was 13 days) when his blood flow of ECMO was decreased to less than $2 \mathrm{~L} / \mathrm{min}$ with a significant improvement on his chest X-ray. The patient turned to high fever in the following days. Repeated PCR for H7N9 virus were tested and show continuous negative in the lower respiratory samples after a week of ICU admission. Advanced antibiotics and antifungal agents were administered, no positive pathogenic result was emerged, and PCT level remained downtrend. The chest CT on day 17 shows bilateral GGO with aggravating consolidation on new areas (Fig. 1), compatible with organizing pneumonia (OP). Considering no underlying cause of OP existed other than virus infection, therefore, OP associated with H7N9 influenza virus infection was suspected. Methylprednisolone $80 \mathrm{mg}(1 \mathrm{mg} / \mathrm{kg})$ daily was applied on day 17 for 5 days with tapering. With clinical improvement, the patient was extubated on day 21, and supported with NIV with a $\mathrm{FiO}_{2}$ of 0.6. The chest CT on day 26 showed obvious remission of consolidation with patchy GGO and fibrotic changes.

However, the clinical condition of the patient deteriorated again on day 31 with high fever to $40^{\circ} \mathrm{C}$, refractory hypoxemia $\left(\mathrm{PaO}_{2}: \mathrm{FiO}_{2}=65\right)$ and a mild leukopenia (WBC was $11.92 \times 10^{9} / \mathrm{L}$ ). the patient was reintubated and supported with invasive mechanical ventilation. Methylprednisolone $80 \mathrm{mg}$ daily was applied at the

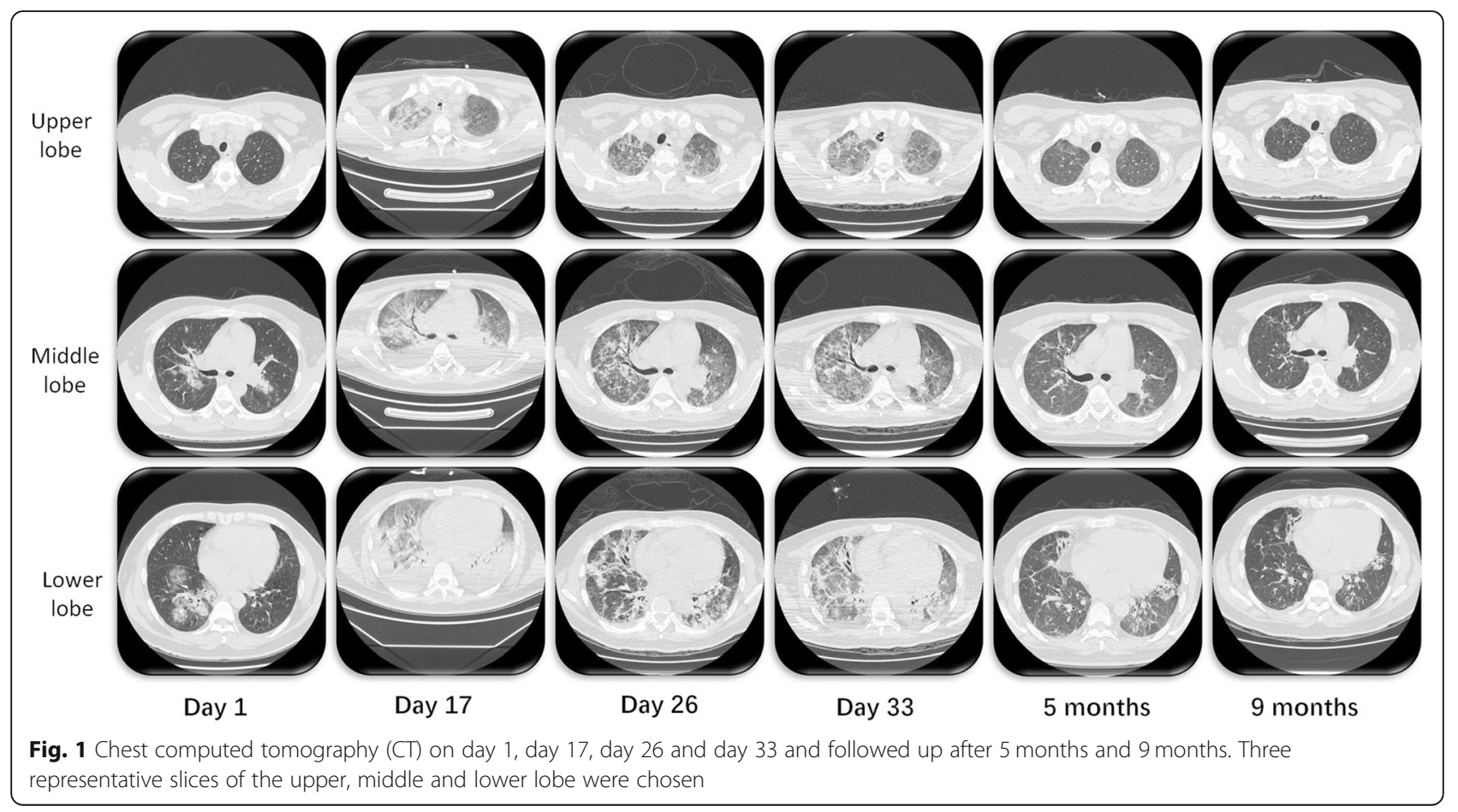


beginning as a suspicion of the relapse of OP. And chest $\mathrm{CT}$ on day 33 revealed progression of consolidation especially in the lower lobe. As the patient's respiratory failure and condition did not improve after 5 days of daily use of methylprednisolone $80 \mathrm{mg}$, histological examination was done via open lung biopsy (OLB) on day 35, and OP was confirmed with the presence of intraluminal plugs of granulation tissue within alveolar ducts and surrounding alveoli associated with chronic inflammation of the surrounding lung parenchyma. The therapy of steroid was changed to methylprednisolone $120 \mathrm{mg}(1.5 \mathrm{mg} / \mathrm{kg})$ for 5 days, $80 \mathrm{mg}$ for 7 days, $40 \mathrm{mg}$ for 7 days. The oxygenation improved, and the patient was extubated on day 57 and discharged on day 71 . A time line of the steroids use, white cell count and ratio of $\mathrm{PaO}_{2} / \mathrm{FiO}_{2}$ is illustrated in Fig. 2 .

The following-up for 10 months from onset of primary virus infection showed gradually improvement, with mild interlobular septal thickening, traction bronchiectasis and consolidation in chest CT on the ninth month (Fig. 1).

\section{Literature review}

As shown in Tables 1, 13 previously published cases and the current case of OP associated with influenza virus infection were reviewed [3-10]. With available information, the age range was 24-year-old to 97year-old with 64\% (9/14) female. Influenza A constituted the majority $(93 \%, 13 / 14)$, with 8 cases were identified to $\mathrm{H} 1 \mathrm{~N} 1$, and the current case, H7N9. The other one case was OP complicated with co-infection of influenza B and Streptococcus. Respiratory failure associated with OP was reported in $64 \%(7 / 11)$ patient. Fever $(27 \%, 3 / 11)$, dyspnea $(36 \%, 4 / 11)$, cough $(27 \%, 3 / 11)$ were the most common symptoms reported. Especially, clinical condition deteriorated after controlling of primary disease can be found in $64 \%$ (7/11) patients. GGO and consolidation were the main findings on high resolution computed tomography (HRCT), shown in $50 \%(6 / 12)$ and $67 \%(8 / 12)$ of cases, with release of primary opacity associated with influenza infection in some cases. Autopsy were applied at about two weeks and most transbronchial lung biopsy (TBLB) or open lung biopsy (OLB) were applied over three weeks. Steroid was the main treatment, varying from prednisolone $30 \mathrm{mg} /$ day to methylprednisolone $500 \mathrm{mg} /$ day pulse therapy, with or without tapering. Most patients react well to the treatment with clinical and radiological improvement, excepting the relapsing of OP in our case.

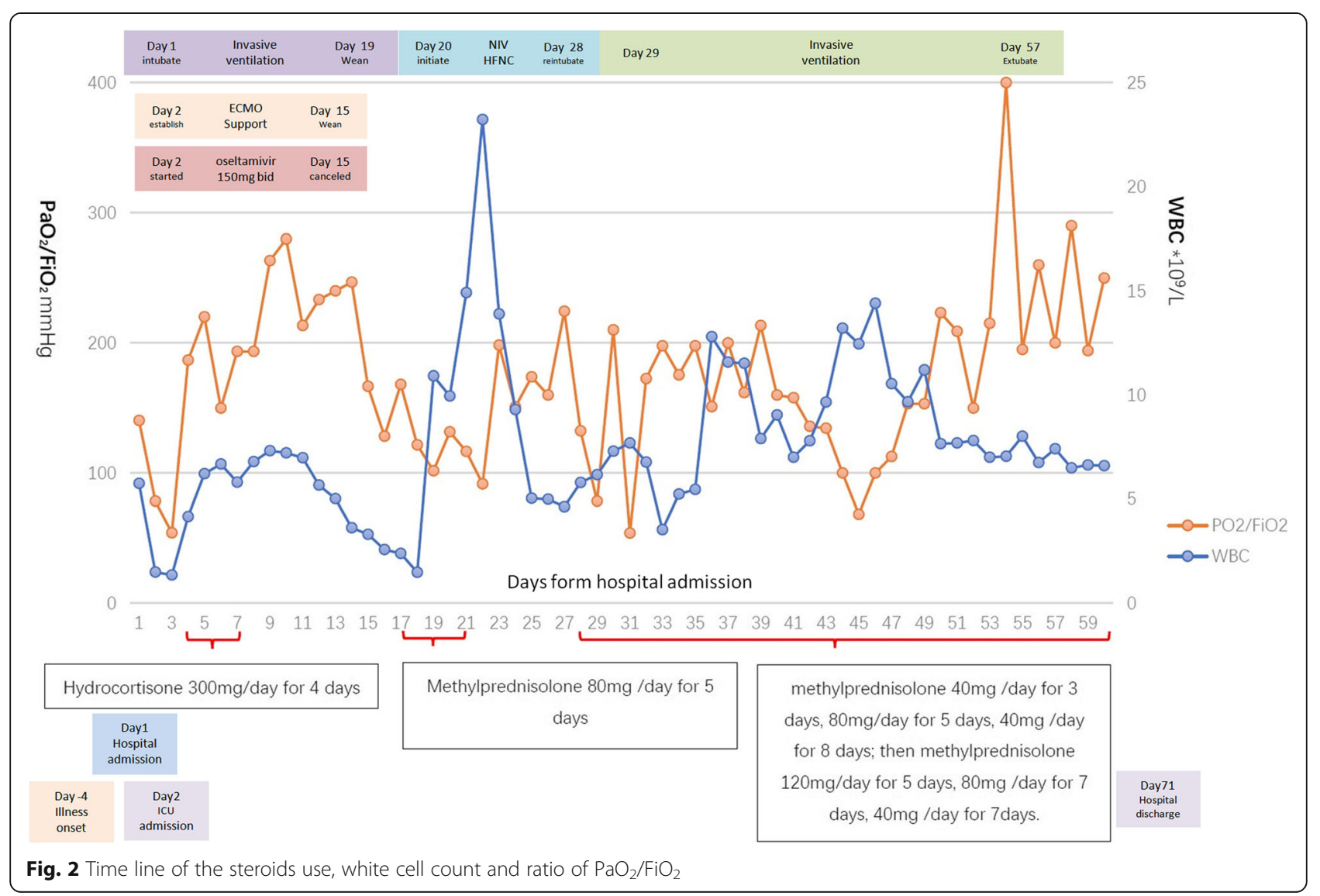


Table 1 Cas series reported organizing pneumonia associated with influenza viral infection

\begin{tabular}{|c|c|c|c|c|c|c|c|c|c|c|}
\hline Citation & Age & Gender & $\begin{array}{l}\text { Virus } \\
\text { type }\end{array}$ & Manifestation & $\mathrm{HRCT}$ & $\begin{array}{l}\text { Time to } \\
\text { biopsy }\end{array}$ & $\begin{array}{l}\text { Biopsy/ } \\
\text { autopsy }\end{array}$ & Pathology & Treatment & Outcome \\
\hline $\begin{array}{l}\text { Staud, } \\
2001[4]\end{array}$ & 59 & $\mathrm{~F}$ & A & Respiratory failure & Consolidation & NR & OLB & $\mathrm{OP}$ & $\begin{array}{l}\text { Intravenous steroids } \\
\text { and azathioprine }\end{array}$ & Survival \\
\hline $\begin{array}{l}\text { Fujita, } \\
2007[6]\end{array}$ & 38 & $\mathrm{~F}$ & A & NR & Consolidation & NR & NR & $\mathrm{OP}$ & $\begin{array}{l}\text { Steroid pulse } \\
\text { therapy }\end{array}$ & Survival \\
\hline \multirow[t]{3}{*}{$\begin{array}{l}\text { Fujita, } \\
2014[7]\end{array}$} & 97 & $\mathrm{~F}$ & A & Respiratory failure & Not examined & 12 days & Autopsy & $\begin{array}{l}\text { OP, DAD, } \\
\text { hemorrhage } \\
\text { and } \\
\text { bronchiolitis }\end{array}$ & NR & Dead \\
\hline & 24 & $\mathrm{~F}$ & $\mathrm{H} 1 \mathrm{~N} 1$ & Respiratory failure & $\begin{array}{l}\text { Consolidation } \\
\text { and GGO }\end{array}$ & 16 days & Autopsy & $\mathrm{OP}$ and $\mathrm{DAD}$ & $N R$ & Dead \\
\hline & 37 & M & H1N1 & Respiratory failure & GGO & 15 days & Autopsy & $\begin{array}{l}\text { OP, } \\
\text { hemorrhage } \\
\text { and edema }\end{array}$ & NR & Dead \\
\hline $\begin{array}{l}\text { Marchiori, } \\
2011[8]\end{array}$ & 52 & M & H1N1 & NR & linear opacity & NR & NR & $\mathrm{OP}$ & NR & $N R$ \\
\hline $\begin{array}{l}\text { Torrego, } \\
2010[9]\end{array}$ & 55 & $\mathrm{~F}$ & H1N1 & Dyspnea and cough & Consolidation & $\begin{array}{l}\text { Over } \\
30 \text { days }\end{array}$ & TBLB & $\begin{array}{l}\text { OP with viral } \\
\text { cytopathic } \\
\text { changes }\end{array}$ & $\begin{array}{l}\text { Prednisone, } 0.75 \mathrm{mg} / \\
\mathrm{kg} / \mathrm{d}\end{array}$ & $\begin{array}{l}\mathrm{C} / \mathrm{R} \\
\text { improvement }\end{array}$ \\
\hline \multirow[t]{2}{*}{$\begin{array}{l}\text { Cornejo, } \\
2010[3]\end{array}$} & 52 & $\mathrm{~F}$ & H1N1 & Respiratory failure & Consolidation & $\begin{array}{l}\text { Over } 8 \\
\text { days }\end{array}$ & OLB & $\begin{array}{l}\text { OP, bronchiolar } \\
\text { necrosis and } \\
\text { squamous } \\
\text { metaplasia }\end{array}$ & $\begin{array}{l}\text { Methylprednisolone, } \\
500 \mathrm{mg} / \mathrm{d} \text { for 3d }\end{array}$ & improvement \\
\hline & 36 & M & H1N1 & $\begin{array}{l}\text { Fever, increased } \\
\text { inflammatory } \\
\text { parameters, and } \\
\text { respiratory failure }\end{array}$ & $\begin{array}{l}\text { Consolidation } \\
\text { and loss of } \\
\text { global lung } \\
\text { volume }\end{array}$ & $\begin{array}{l}\text { Over } 3 \\
\text { weeks }\end{array}$ & OLB & $\begin{array}{l}\text { OP, } \\
\text { hemorrhage } \\
\text { and edema }\end{array}$ & The same as above & $\begin{array}{l}\mathrm{C} / \mathrm{R} \\
\text { improvement }\end{array}$ \\
\hline \multirow[t]{2}{*}{$\begin{array}{l}\text { Gómez- } \\
\text { Gómez, } \\
2011 \text { [10] }\end{array}$} & 44 & $\mathrm{~F}$ & H1N1 & $\begin{array}{l}\text { Cough, dyspnea } \\
\text { and fever }\end{array}$ & $\begin{array}{l}\text { Intralobular } \\
\text { interstitial } \\
\text { thickening } \\
\text { and GGO }\end{array}$ & $\begin{array}{l}\text { Over } 3 \\
\text { weeks }\end{array}$ & TBLB & $\mathrm{OP}$ & $\begin{array}{l}\text { Steroid, } 1 \mathrm{mg} / \mathrm{kg} / \mathrm{day} \\
\text { for } 1 \mathrm{~m} 0.5 \mathrm{mg} / \mathrm{kg} / \mathrm{d} \\
\text { for } 6 \mathrm{w}\end{array}$ & $\begin{array}{l}\mathrm{C} / \mathrm{R} \\
\text { improvement }\end{array}$ \\
\hline & 60 & M & $\mathrm{H} 1 \mathrm{~N} 1$ & $\begin{array}{l}\text { Cough and } \\
\text { dyspnea }\end{array}$ & $\begin{array}{l}\text { Consolidation } \\
\text { and GGO }\end{array}$ & $\begin{array}{l}\text { Over } 3 \\
\text { weeks }\end{array}$ & TBLB & $\mathrm{OP}$ & The same as above & $\begin{array}{l}\mathrm{C} / \mathrm{R} \\
\text { improvement }\end{array}$ \\
\hline \multirow[t]{2}{*}{$\begin{array}{l}\text { Kwok, } \\
2016[5]\end{array}$} & 45 & $\mathrm{~F}$ & B & Dyspnea & $\begin{array}{l}\text { GGO and } \\
\text { lung cyst }\end{array}$ & $\begin{array}{l}\text { Over } \\
28 \text { days }\end{array}$ & TBLB & $\mathrm{OP}$ & $\begin{array}{l}\text { Prednisolone, } 30 \\
\text { mg/d with } 2 \text { m } \\
\text { tapering }\end{array}$ & $\begin{array}{l}\mathrm{C} / \mathrm{R} \\
\text { improvement }\end{array}$ \\
\hline & NR & $\mathrm{F}$ & A & NR & NR & NR & $N R$ & NR & Steroid & $\begin{array}{l}\text { Improvement } \\
\text { with lung } \\
\text { fibrosis and } \\
\text { residual dyspnea }\end{array}$ \\
\hline This case & 35 & M & H7N9 & $\begin{array}{l}\text { Fever, respiratory } \\
\text { failure }\end{array}$ & $\begin{array}{l}\text { Consolidation } \\
\text { and GGO }\end{array}$ & 39 days & OLB & $\begin{array}{l}\text { OP, } \\
\text { hemorrhage } \\
\text { and edema }\end{array}$ & $\begin{array}{l}\text { Methylprednisolone, } \\
1.5 \mathrm{mg} / \mathrm{kg} / \mathrm{d} \text { for } 5 \mathrm{~d} \text {, }\end{array}$ & $\begin{array}{l}\mathrm{C} / \mathrm{R} \\
\text { improvement }\end{array}$ \\
\hline
\end{tabular}

\section{Discussion and conclusions}

Since the cases infected with avian influenza H7N9 virus were first confirmed in 2013 in China [1, 2], five seasonal epidemics were observed, with an earlier start and a steep increase in infected number in the latest epidemic [11]. In a clinical study including 111 cases confirmed $\mathrm{H} 7 \mathrm{~N} 9$ virus infection, $76.6 \%$ were admitted to an ICU and $27 \%$ died. The median time from the exposure to disease onset was five days, then, 6.8 days to acute respiratory distress syndrome (ARDS). In dead cases, the median time from disease onset to death was 14 days [12]. Half of the patients required mechanical ventilation and $21 \%$ need ECMO for severe respiratory failure $[1,2]$. However, refractory severe respiratory failure caused by OP secondary to avian influenza H7N9 virus infection was first reported in this case.

OP was originally described by Davison et al. in 1983 [13] (1), and in 1985, Epler et al. described the same entity as the term "bronchiolitis obliterans organizing pneumonia" (BOOP) [14]. Now, for avoiding confusion with bronchiolitis obliterans (BO), the term organizing pneumonia (OP) is preferred [15]. In fact, $O P$ is an nonspecific inflammatory response from human body towards acute lung injuries. It can be with idiopathic 
nature, namely cryptogenic organizing pneumonia (COP), or be associated with different clinical settings, such as infections (bacteria, virus, fungus or parasite), drugs (antibiotics, antiepileptics, immunomodulators), connective tissue disease, vasculitis or lung/marrow transplantation. Considering symptomatology, physical signs, laboratory and pulmonary function tests, radiologic or histomorphological findings, there is no obvious difference between COP and secondary OP, excepting the latter may have higher mortality [16].

OP has been linked to multiple influenza viral infections including influenza $\mathrm{A}$ and $\mathrm{B}$, but this is the first report of avian influenza H7N9-associated OP with relapse occurrence and severe respiratory failure. The main clinical features of our avian influenza H7N9-associated OP is similar to the cases of influenza A cases. In these cases reported, OP onset mostly at the second to third week in the course of influenza, and occurred after the releasing of primary virus infection; And the OP is complicated with respiratory failure, and no evidence of other pathogen was found; And the main findings on HRCT for this kind of OP were GGO and consolidation. Biopsy were done via TBLB or OLB at the third week. In cases with influenza associated OP, other than common findings of OP, diffuse alveolar damage (DAD), alveolar hemorrhage and edema and bronchiolitis can also be found, showing the lung injury of primary virus infection. However, in our case, the patient present with high fever as a main manifestation of OP, and had a relapse of respiratory failure associated with OP. A differential diagnosis of OP should be considered at the second to third week after the primary infection among patients with influenza H7N9 infection. Furthermore, there was no clear evidence of bacterial and fungus infection during the beginning of hospitalization. However, the levels of PCT and galactomannan showed significant increase after the patient was established with ECMO. The OP may also be caused by the nosocomial infection which was frequently complicated with severe influenza pneumonia.

The majority of patients with OP show rapid responding to steroids. The introduced initial dose is prednisone $0.5-1.0 \mathrm{mg} / \mathrm{kg}$, with tapering over 6-12 month. However, up to one-third patients may relapse in tapering period. For the current patient with avian influenza H7N9associated OP, methylprednisolone $80 \mathrm{mg}(1 \mathrm{mg} / \mathrm{kg})$ daily was applied for 5 days with tapering in the beginning of suspicion of OP. The patient showed rapid clinical and radiological improvement and was extubated on the fifth day of steroids applying. However, the patient deteriorated with high fever and refractory hypoxemia 10 days later. With the confirmation of histological examination, steroid dose was increased to methylprednisolone 120 $\mathrm{mg}(1.5 \mathrm{mg} / \mathrm{kg})$ daily for 5 days. And OP was finally controlled without relapsing in follow-ups. Insufficient initial dose of steroid may contributed to the relapsing of OP before final diagnosis. Therefore, Post avian influenza H7N9 infection OP may responsive to a brief course (weeks) of moderate-to-high dose prednisone therapy.

To the best of our knowledge, this was the first case of OP associated with avian influenza H7N9 infection. With clinical manifestation and radiological findings compatible with OP, a differential diagnosis should be considered among patients with influenza H7N9 infection at the second or third week after the initial viral infection, especially in patients with clinical condition deteriorated after controlling of primary influenza pneumonia. And a steroid dose of methylprednisolone $1.5 \mathrm{mg} / \mathrm{kg}$ maybe suggested for treatment of OP associated with avian influenza H7N9 infection. Our case provide clinical insight into refractory respiratory failure with lung involvement due to avian influenza H7N9. OP should be considered on the differential diagnosis of patients with fever and respiratory failure after severe influenza A H7N9 infection, where steroids might be useful.

\section{Abbreviations \\ ARDS: Acute respiratory distress syndrome; GGO: Ground-glass opacity; ICU: Intensive care unit; OLB: Open lung biopsy; OP: Organizing pneumonia}

\section{Acknowledgements \\ No acknowledgement. \\ Authors' contributions \\ All authors made substantial contributions to conception and design, or acquisition of data, or analysis and interpretation of data; reviewed and approved the final manuscript; and contributed significantly to this study. $\mathrm{HH}$ takes full responsibility for the integrity of the submission and publication, and was involved in study design. $\mathrm{HW}$ and $\mathrm{HH}$ had full access to all the data in the study and take responsibility for the integrity of the data and the accuracy of the data analysis, and was responsible for data verification, analysis and drafting of the manuscript. BS, ZT had full access to all the data in the study and takes responsibility for the integrity of the data and the accuracy of the data analysis. XT and XL were responsible for the data collection. All authors read and approve the final manuscript.}

\section{Funding}

Not applicable.

Availability of data and materials

Not applicable.

Ethics approval and consent to participate

We did not commence any experimental use of a novel procedure or tool in this case, and all therapy was approved by an ethics committee of our hospital.

\section{Consent for publication}

Written informed consent was obtained from the patient for publication of this Case Report and any accompanying images. A copy of the written consent is available for review by the Editor of this journal.

Competing interests

The authors declare that they have no competing interests. 
Received: 12 September 2018 Accepted: 23 July 2019

Published online: 29 July 2019

\section{References}

1. Gao R, Cao B, Hu Y, Feng Z, Wang D, Hu W, Chen J, Jie Z, Qiu H, Xu K, et al. Human infection with a novel avian-origin influenza a (H7N9) virus. N Engl J Med. 2013;368(20):1888-97.

2. Chen Y, Liang W, Yang S, Wu N, Gao H, Sheng J, Yao H, Wo J, Fang Q, Cui $D$, et al. Human infections with the emerging avian influenza a H7N9 virus from wet market poultry: clinical analysis and characterisation of viral genome. Lancet. 2013;381(9881):1916-25.

3. Cornejo R, Llanos O, Fernandez C, Carlos Diaz J, Cardemil G, Salguero J, Luengo C, Tobar E, Romero C, Galvez LR. Organizing pneumonia in patients with severe respiratory failure due to novel a (H1N1) influenza. BMJ Case Rep. 2010;2010.

4. Staud R, Ramos LG. Influenza A-associated bronchiolitis obliterans organizing pneumonia mimicking Wegener's granulomatosis. Rheumatol Int. 2001;20(3):125-8.

5. Kwok WC, Lam SH, Wong MP, Ip MS, Lam DC. Influenza B/streptococcal coinfection complicated by organizing pneumonia. Respirol Case Rep. 2016; 4(5):e00170

6. Fujita J, Bandoh S, Yamaguchi M, Higa F, Tateyama M. Chest CT findings of influenza virus-associated pneumonia in 12 adult patients. Influenza Other Respir Viruses. 2007;1(5-6):183-7.

7. Fujita J, Ohtsuki Y, Higa H, Azuma M, Yoshinouchi T, Haranaga S, Higa F, Tateyama M. Clinicopathological findings of four cases of pure influenza virus a pneumonia. Intern Med. 2014;53(12):1333-42.

8. Marchiori E, Zanetti G, Fontes CA, Santos ML, Valiante PM, Mano CM, Teixeira GH, Hochhegger B. Influenza a (H1N1) virus-associated pneumonia: high-resolution computed tomography-pathologic correlation. Eur J Radiol. 2011;80(3):e500-4.

9. Torrego A, Pajares V, Mola A, Lerma E, Franquet T. Influenza A (H1N1) organising pneumonia. BMJ Case Rep. 2010;2010.

10. Gomez-Gomez A, Martinez-Martinez R, Gotway MB. Organizing pneumonia associated with swine-origin influenza a H1N1 2009 viral infection. AJR Am J Roentgenol. 2011;196(1):W103-4.

11. Zhou L, Ren R, Yang L, Bao C, Wu J, Wang D, Li C, Xiang N, Wang Y, Li D, et al. Sudden increase in human infection with avian influenza a(H7N9) virus in China, September-December 2016. Western Pac Surveill Response J. 2017; 8(1):6-14.

12. Gao HN, Lu HZ, Cao B, Du B, Shang H, Gan JH, Lu SH, Yang YD, Fang Q, Shen $Y Z$, et al. Clinical findings in 111 cases of influenza a (H7N9) virus infection. N Engl J Med. 2013;368(24):2277-85.

13. Davison AG, Heard BE, MCAllister WA, Turner-Warwick ME. Cryptogenic organizing pneumonitis. Q J Med. 1983;52(207):382-94.

14. Epler GR, Colby TV, McLoud TC, Carrington CB, Gaensler EA. Bronchiolitis obliterans organizing pneumonia. N Engl J Med. 1985;312(3):152-8.

15. American Thoracic S, European Respiratory S. American Thoracic Society/ European Respiratory Society international multidisciplinary consensus classification of the idiopathic interstitial pneumonias. This joint statement of the American Thoracic Society (ATS), and the European Respiratory Society (ERS) was adopted by the ATS board of directors, June 2001 and by the ERS executive committee, June 2001. Am J Respir Crit Care Med. 2002; 165(2):277-304.

16. Roberton BJ, Hansell DM. Organizing pneumonia: a kaleidoscope of concepts and morphologies. Eur Radiol. 2011;21(11):2244-54.

\section{Publisher's Note}

Springer Nature remains neutral with regard to jurisdictional claims in published maps and institutional affiliations.

Ready to submit your research? Choose BMC and benefit from:
- fast, convenient online submission
- thorough peer review by experienced researchers in your field
- rapid publication on acceptance
- support for research data, including large and complex data types
- gold Open Access which fosters wider collaboration and increased citations
- maximum visibility for your research: over 100M website views per year
At BMC, research is always in progress.
Learn more biomedcentral.com/submissions

